\title{
Aktualisasi nilai-nilai pancasila dan konstitusi melalui pelokalan kebijakan Hak Asasi Manusia (HAM) di daerah
}

\author{
Ana Fauzia'; Fathul Hamdani²*) \\ Published online: 5 July 2021
}

\begin{abstract}
Penegakan hak asasi manusia (HAM) salah satunya dilakukan melalui pemenuhan hak-hak dasar manusia. Upaya pemenuhan hak-hak dasar manusia di daerah ini turut menjadi perhatian dari pemerintah pusat melalui program Kabupaten/Kota Peduli Hak Asasi Manusia (KKP HAM) yang dilaksanakan oleh Kementerian Hukum dan Hak Asasi Manusia (Kemenkumham). Namun sayangnya, hanya 59 persen dari total kabupaten/kota di Indonesia yang dinyatakan peduli terhadap HAM. Tentu kondisi ini menunjukkan bahwa penegakan HAM masih belum merata di setiap daerah. Tujuan dari penelitian ini yaitu memberikan telaah terkait perwujudan nilai-nilai pancasila dan konstitusi dalam penegakan HAM yakni melalui pelokalan kebijakan HAM di daerah yang selama ini belum optimal dan belum melibatkan partisipasi masyarakat secara menyeluruh. Metode penelitian yang digunakan yaitu penelitian normatif dengan menggunakan pendekatan perundang-undangan dan konseptual. Dari hasil penelitian mengetengahkan suatu konsepsi terkait penegakan HAM yang tidak boleh terpisahkan dari nilai-nilai pancasila dan konstitusi. Aktualisasi nilai-nilai pancasila dan konstitusi dapat dikatakan merupakan ruh dalam penegakan HAM. Karena berhasil tidaknya suatu penegakan HAM sangat bergantung dari sejauh mana nilai-nilai pancasila dan konstitusi dilaksanakan dalam tertib kehidupan bermasyarakat, berbangsa dan bernegara. Sehingga dalam konteks aktualisasi nilai-nilai pancasila dan konstitusi melalui pelokalan kebijakan HAM di daerah, diharapkan dapat meningkatkan kesadaran masyarakat terkait upaya penghormatan dan kepedulian terhadap HAM.
\end{abstract}

Keyword: Nilai-Nilai Pancasila dan Konstitusi; Pelokalan Kebijakan HAM; Penegakan HAM

\section{PENDAHULUAN}

Dalam konteks bernegara, Pancasila merupakan falsafah kenegaraan atau staatsidee (cita negara) yang berfungsi sebagai filosofische grondslag dan common platforms atau kalimatun sawa di antara sesama warga masyarakat. Pancasila mempuyai tempat yang sangat penting karena merupakan kesepakatan (consensus) berkenaan dengan cita-cita bersama yang sangat menentukan tegaknya konstitusi dan konstitusionalisme di Indonesia. Karena cita-cita bersama itulah yang pada puncak abstraksinya paling mungkin mencerminkan kesamaan-kesamaan kepentingan di antara sesama warga masyarakat yang dalam kenyataannya harus hidup di tengah pluralisme atau kemajemukan (Jimly Asshiddiqie, 2009). Atas dasar tersebut, lahirlah kesepakatan kedua, yakni konstitusi yang memuat kesepakatan umum atau persetujuan (consensus) di antara mayoritas rakyat mengenai bangunan yang diidealkan berkenaan dengan negara, bahwa apapun yang hendak dilakukan dalam konteks penyelenggaraan negara haruslah didasarkan atas rule of the game yang ditentukan bersama.

${ }^{1}$ Fakultas Hukum Universitas Muhammadiyah Malang

${ }^{2}$ Fakultas Hukum Universitas Mataram

*) corresponding author

Fathul Hamdani

Email: fhmdnny@gmail.com
Istilah yang biasa digunakan untuk itu adalah negara hukum (the rule of law) yang dipelopori oleh A.V. Dicey, seorang sarjana Inggris kenamaan (Jimly Asshiddiqie, 2008: 6).

Indonesia diidealkan dan dicita-citakan oleh the founding fathers sebagai suatu Negara Hukum 
(Rechtsstaat/The Rule of Law). Konsep negara hukum tersebut kemudian tercermin dalam Pasal 1 ayat (3) Undang-Undang Dasar Negara Republik Indonesia Tahun 1945 (UUD NRI Tahun 1945) yang menegaskan bahwa "Negara Indonesia adalah Negara Hukum". Keberadaan Indonesia sebagai negara hukum menuntut adanya tanggung jawab negara dalam memberikan perlindungan, pemajuan, penegakan, dan pemenuhan terhadap hak asasi manusia (HAM) sebagaimana ketentuan Pasal 28I ayat (4) UUD NRI Tahun 1945. Hal ini mengingat bahwa salah satu ciri negara hukum adalah adanya jaminan terhadap HAM (Kif Aminanto, 2018: 98-102).

Pernyataan HAM di dalam Pancasila mengandung pemikiran bahwa manusia diciptakan oleh Tuhan Yang Maha Esa dengan menyandang dua aspek yakni, aspek individualitas (pribadi) dan aspek sosialitas (bermasyarakat). Oleh karena itu, kebebasan setiap orang dibatasi oleh hak asasi orang lain. Ini berarti, bahwa setiap orang mengemban kewajiban mengakui dan menghormati hak asasi orang lain. Kewajiban ini juga berlaku bagi setiap organisasi pada tatanan manapun, terutama negara dan pemerintah khususnya di Negara Indonesia (Bambang Heri Supriyanto, 2014: 153). Adapun Ir. Soekarno pernah berkata bahwa filsafat pancasila itu berjiwa kekeluargaan ini disebabkan, karena pertama-tama pancasila ini untuk pertama kalinya disajikan kepada khalayak ramai sebagai dasar filsafat negara Republik Indonesia yang kelak akan didirikan, dan kehidupan manusia yang didasari filsafat pancasila, jadi bangsa Indonesia itu melihatnya sebagai suatu kehidupan kekeluargaan (Sri Soemantri, 1992: 3). Sehingga penting dalam penegakan HAM harus melibatkan berbagai pihak, yang di dalam pelaksanaanya bersumber pada nilai-nilai pancasila dan konstitusi.

Dalam rangka memberikan perlindungan pemajuan, penegakan, dan pemenuhan terhadap HAM tersebut, pemerintah pusat membuat suatu program yang dinamakan Kabupaten/Kota Peduli Hak Asasi Manusia (KKP HAM) yang dilaksanakan oleh Kementerian Hukum dan Hak Asasi Manusia. Hal ini merupakan bagian dari upaya pemerintah pusat untuk melakukan pemenuhan terhadap hakhak dasar manusia di daerah. Kewajiban negara terhadap perlindungan pemajuan, penegakan, dan pemenuhan terhadap HAM akan terlaksana dengan baik apabila adanya kerjasama yang baik antara pemerintah pusat dan pemerintah daerah. Sebab, berbagai isu HAM secara substansi melekat dalam urusan pemerintahan daerah yang bersifat wajib (Inna Junaenah \& Lailani Sungkar, 2017: 494). Selain itu, isu terkait HAM juga tercermin dalam program Sustainable Development Goals (SDGs) yang telah menjadi komitmen pemerintah. Tujuan SDGs sebagaimana dimaksud tercermin dalam tujuan (goal) ke-11, yaitu: "Make cities and human settlements inclusive, safe, resilient, and sustainable" (Liz Ford, 2015).

Untuk mewujudkan tujuan tersebut, pemerintah pusat memiliki kepentingan terhadap daerah, sebab banyak persoalan yang akan dihantarkan oleh SDGs yang berfokus di daerah. Keberhasilan terhadap pencapaian tersebut, khususnya dalam menciptakan rasa kepedulian dan penghormatan terhadap HAM demi tegaknya HAM sangat bergantung dari kerjasama serta jiwa kekeluargaan satu sama lain. Sehingga sangat wajar dan layak apabila upaya mengaktualisasikan nilai-nilai pancasila dan konstitusi dilakukan dengan melakukan pelokalan terhadap kebijakan HAM di daerah. Walaupun upaya pelokalan kebijakan HAM di daerah ini telah dilakukan melalui berbagai kebijakan HAM, seperti yang telah disebutkan, yakni KKP HAM maupun Kota Ramah HAM, namun sayangnya hanya 59 persen dari total kabupaten/kota di Indonesia yang dinyatakan peduli terhadap HAM (Kementerian Hukum dan HAM, 2020). Tentu kondisi ini menyisakan beberapa pertanyaan, baik pada tataran perencanaan maupun terkait pelaksanaanya dilapangan. Oleh karena itu, dalam penelitian ini dirasa perlu upaya lebih dengan keterlibatan berbagai pihak, khususnya masyarakat mulai dari tingkat daerah atau dengan kata lain pelokalan kebijakan HAM di daerah yang bersumber pada nilai-nilai pancasila dan konstitusi. Dalam rangka aktualisasi nilai-nilai pancasila dan konstitusi melalui pelokalan kebijakan HAM di daerah, maka beberapa hal yang perlu dikaji yaitu terkait posisi pancasila dan konstitusi dalam upaya perlindungan, pemajuan, penegakan, dan pemenuhan terhadap HAM di Indonesia, serta upaya yang dapat dilakukan dalam mewujudkan pelokalan kebijakan HAM di daerah menurut nilai-nilai pancasila dan konstitusi. 


\section{BAHAN DAN METODE}

Dalam penelitian ini, metode yang digunakan adalah penelitian hukum normatif dengan menggunakan pendekatan peraturan perundang-undangan, konseptual dan historis. Pendekatan peraturan perundang-undangan yang dimaksud adalah segala bentuk perundang-undangan yang berkaitan dengan HAM. Kemudian dalam kerangka konseptual, Penulis mengaji konsep-konsep dalam penegakan hak asasi manusia, dan nilai-nilai HAM dalam pancasila dan konstitusi. Sementara pada pendekatan historis, Penulis menguraikan sejarah dan contoh pelokalan kebijakan HAM di negara lain.

\section{HASIL DAN PEMBAHASAN}

\section{Posisi Pancasila dan Konstitusi dalam Upaya Perlindungan, Pemajuan, Penegakan, dan Pemenuhan terhadap HAM di Indonesia}

Hak asasi manusia (HAM) dalam bahasa Perancis disebut "Droit L'Homme”, yang artinya hakhak manusia dan dalam bahasa Inggris disebut Human Rights. Seiring dengan perkembangan ajaran negara hukum, dimana manusia atau warga negara mempunyai hak-hak utama dan mendasar yang wajib dilindungi oleh Pemerintah, maka muncul istilah Basic Rights atau Fundamental Rights. Apabila diterjemahkan ke dalam bahasa Indonesia adalah merupakan hak-hak dasar manusia atau lebih dikenal dengan istilah hak asasi manusia (HAM) (Rizky Ariestandi Irmansyah, 2013: 61).

Salah satu sifat HAM adalah universal. Sebagaimana dikatakan oleh Muhammad Ridha Iswardhana dalam bukunya yang berjudul "Pendidikan Pancasila dan Kewarganegaraan", universal berarti berlaku bagi setiap orang tanpa memandang latar belakang suku, agama, ras, dan kelompok apapun. Karena bersifat universal, negara wajib menegakkan hak asasi setiap warga negaranya tanpa terkecuali (M. Ridha Iswardhana, 2020: 99). Di Indonesia, penegakkan HAM didasarkan pada ideologi negara, yaitu Pancasila. Pancasila pada dasarnya memberikan jaminan terhadap HAM melalui nilai-nilai yang dimilikinya. Ada tiga nilai yang terkandung dalam pancasila, yaitu (M. Ridha Iswardhana, 2020: 100-102):

a. Nilai ideal

Nilai ideal merupakan nilai yang berhubungan dengan hakikat kelima sila Pancasila. Nilai ideal bersifat universal sehingga di dalamnya terkandung cita-cita, tujuan, dan nilai-nilai yang baik dan benar. Penjabarannya yaitu: Sila pertama, menjamin kemerdekaan untuk memeluk agama, menjalankan ibadah, dan menghormati perdedaan agama; Sila kedua, memposisikan setiap warga negara pada kedudukan yang sama dalam hukum; Sila ketiga, memberikan semangat persatuan di antara warga negara dan menempatkan kepentingaan bangsa dan negara di atas kepentingan pribadi atau golongan; Sila keempat, mengajarkan untuk menghargai hak setiap warga negara untuk bermusyawarah mufakat yang dilakukan tanpa adanya tekanan ataupun paksaan; Sila kelima, mengakui hak milik perorangan dan dilindungi pemanfaatannya oleh negara.

b. Nilai instrumental

Nilai instrumental merupakan penjabaran dari nilai-nilai ideal Pancasila. Dengan kata lain, nilai instrumental merupakan pedoman pelaksanaan kelima sila Pancasila. Pada dasarnya nilai instrumental tersebut berbentuk ketentuan konstitusional, seperti undang-undang hingga peraturan daerah yang di dalamnya menjamin keberadaan HAM. 


\section{c. Nilai Praksis}

Nilai praksis merupakan realisasi nilai instrumental dalam kehidupan sehari-hari. Hak asasi manusia dalam nilai praksis dapat terwujud jika nilai dasar dan nilai instrumental dapat diterapkan dalam kehidupan sehari-hari setiap warga negara.

Dari uraian di atas, dapat dilihat bahwa posisi pancasila dalam penegakan HAM memang sangat sentral, terlebih pancasila merupakan filosofische grondslag dan common platforms atau kalimatun sawa di antara sesama warga masyarakat. Dalam rangka penegakan HAM, bahwa melalui tiga nilai yang terkandung dalam pancasila tersebut, mulai dari tataran ideal, instrumental, dan praksis, tidak boleh terpisahkan satu sama lain. Khususnya terkait nilai praksis yang merupakan realisasi dari nilai ideal dan instrumental, bahwa dalam kehidupan sehari-hari, yakni dalam tertib kehidupan bermasyarakat, berbangsa, dan bernegara, aktualisasi nilai-nilai pancasila menjadi hal yang paling esensial. Sehingga keberhasilan dalam penegakan HAM sangat bergantung pada sejauh mana setiap orang mampu mengaktualisasikan nilai-nilai pancasila dalam dirinya.

Begitupula dalam konstitusi, bahwa materi inti dari naskah Undang-Undang Dasar Negara Republik Indonesia Tahun 1945 (UUD NRI Tahun 1945) adalah adanya jaminan terhadap HAM. Artinya bahwa, kepentingan paling mendasar dari setiap warga negara adalah perlindungan terhadap hak-haknya sebagai manusia. Menurut John Locke dalam bukunya "Second Treaties of Civil Government", bahwa dalam pembentukan negara, John Locke membagi proses perjanjian masyarakat ke dalam dua macam, yakni instansi pertama (the first treaty) yang merupakan perjanjian antara individu dengan individu warga yang ditujukan untuk terbentuknya masyarakat politik dan negara. Instansi pertama ini disebut oleh John Locke sebagai "Pactum Unionis" berdasarkan anggapan bahwa (John Locke, 1953: 111):

"Men by nature are all free, equal, and independent, no one can be put out of this estate, and subjected to the political power another, without his own consent, which other men to join and unite into a community for their comfortable, stafe and peaceable, living one amongst another. . . .".

Dalam instansi berikutnya yang disebutkannya sebagai "Pactum Subjectionis" Locke melihat bahwa pada dasarnya setiap persetujuan antar individu (pactum unionis) terbentuk atas dasar suara mayoritas. Oleh sebab setiap individu selalu memiliki hak-hak yang tak tertanggalkan yakni life, liberty serta estate, maka adalah logis jika tugas negara adalah memberikan perlindungan kepada masing-masing individu. Dasar pemikiran John Locke inilah yang di kemudian dijadikan landasan bagi pengakuan HAM di dunia (Jimly Asshiddiqie, 2008: 8).

Perubahan Kedua UUD NRI Tahun 1945 pada tahun 2000 kemudian menegaskan jaminan konstitusional HAM yang termuat dalam Pasal 28A sampai dengan Pasal 28J, ditambah beberapa ketentuan lainnya yang tersebar di beberapa pasal. Karena itu, perumusan tentang HAM dalam konstitusi Republik Indonesia dapat dikatakan sangat lengkap dan menjadikan UUD NRI Tahun 1945 sebagai salah satu undang-undang dasar yang paling lengkap memuat ketentuan yang memberikan perlindungan terhadap HAM. Pada tataran ini setidaknya dapat dilihat bahwa nilai instrumental dalam pancasila berkaitan dengan HAM telah diakomodir melalui konstitusi. Dengan demikian, negara memiliki kewajiban dalam memberikan perlindungan, pemajuan, penegakan, dan pemenuhan terhadap HAM. Adapun kewajiban negara sebagaimana dimaksud tersebut juga mengikat cabangcabang kekuasaan di bawahnya, yang dalam hal ini adalah pemerintah daerah sebagai perpanjangan tangan dari pemerintah pusat.

Sehingga dalam upaya perlindungan, pemajuan, penegakan, dan pemenuhan terhadap HAM, pemerintah pusat tidak bisa bekerja sendiri, namun juga membutuhkan kerjasama dengan berbagai pihak, salah satunya adalah pemerintah daerah. Keterlibatan pemerintah daerah dalam hal ini bisa dilakukan melalui pelokalan kebijakan HAM di daerah sebagai upaya dalam turut serta menegakkan HAM yang selama ini cenderung terpusat di tingkat nasional. Akan tetapi, upaya dalam mewujudkan pelokalan kebijakan HAM di daerah akan mampu dijalankan dengan baik apabila nilai-nilai yang ada dalam pancasila dan konstitusi dapat diaktualisasikan sebagaimana mestinya. Artinya bahwa 
penegakan HAM dilakukan semata-mata atas dasar ide atau cita-cita yang telah di bangun bersama. Dengan demikian, pancasila dan konstitusi memiliki tempat yang paling tinggi dan merupakan bangunan ideal yang dijadikan acuan dalam konteks kehidupan bernegara, salah satunya adalah terkait perlindungan, pemajuan, penegakan, dan pemenuhan HAM.

\section{Upaya Mewujudkan Pelokalan Kebijakan HAM di Daerah menurut Nilai-Nilai Pancasila dan Konstitusi}

Kewajiban negara untuk menegakkan HAM secara eksplisit tercantum dalam Pasal 28I ayat (4) UUD NRI Tahun 1945 jo. Pasal 71 Undang-Undang Nomor 39 Tahun 199 Tentang Hak Asasi Manusia (UU HAM) yang berbunyi:

"Pemerintah wajib dan bertanggung jawab menghormati,melindungi, menegakkan, dan memajukan hak asasi manusia yang diatur dalam undang-undang ini, peraturan perundangundangan lain dan hukum internasional tentang hak asasi manusia yang diterima oleh negara Republik Indonesia."

Menanggapi pentingnya perlindungan terhadap HAM tersebut, banyak negara telah melakukan berbagai upaya, salah satunya melalui program pembentukan Kota Ramah HAM (Sindi Monica Putri, Weli Febrianto, \& Yosephine Susanto, 2020: 332). Salah satu negara yang menerapkan kebijakan tersebut adalah Kota Gwangju (Korea Selatan) yang merupakan pelopor dari pembentukan Kota Ramah HAM. Pada awalnya, Kota Ramah HAM diselenggarakan oleh Korea Selatan melalui Forum yang dinamakan Forum Kota HAM sedunia. Dari forum tersebut kemudian menghasilkan prinsipprinsip gwangju untuk kota HAM yang dideklarasikan di Gwangju pada tanggal 17 Mei 2014 (Antonio, et.al., 2015). Terkait inovasi yang dilakukan oleh Kota Gwangju (Korea Selatan) tersebut, PBB kemudian merespons dengan cepat yakni dengan mengeluarkan Resolusi Dewan HAM No. 24 tahun 2013 mengenai peran pemerintah daerah dalam penghormatan perlindungan HAM. Pada saat itu, Dewan HAM PBB menugaskan Komite Penasihat Dewan HAM PBB untuk membuat kajian mengenai Pemerintahan Daerah dan HAM melalui resolusi 24/2 September 2013. Adapun hasil dari diskursus tentang HAM tersebut disampaikan dalam Sesi ke-30 Sidang Dewan HAM PBB tanggal 22 September 2015 (Antonio, et.al., 2015). Gagasan ini kemudian berkembang secara global dengan tujuan melokalkan hak asasi manusia.

Dalam mekanisme yang dijelaskan di Resolusi PBB, bahwa kewajiban penegakan HAM utamanya tetap akan dijalankan oleh pemerintah pusat. Namun tetap, sebagai bentuk optimalisasi penyebaran dalam penegakan HAM agar merata di seluruh negara, maka peran dari pemerintah daerah sebagai komplementer dengan memperhatikan pembagian kewenangan pusat dan daerah. Proses pelaksanaan sebagaimana dinyatakan Resolusi PBB akan menjadi pedoman bagi pemerintah daerah di setiap negara dengan berbagai keragaman yang memang sudah disadari oleh Komunitas Internasional. Sehingga, untuk implementasinya, tetap akan bergantung pada konstitusi dan sistem hukum yang berlaku di negara masing-masing. Akan tetapi kewajiban HAM pemerintah daerah tetaplah sama, terutama jika dikaitkan dengan pembangunan daerah (Muhammad Nurkhoirun, 2017: 120-121).

Sebagaimana dijelaskan dalam Deklarasi Gwangju Kota HAM yang peduli akan HAM itu sendiri didefinisikan sebagai komunitas yang bersifat sosial politik dengan ranah lokal atau komunitas lokal. Bahwa proses pendekatan oleh pemerintah daerah dalam memenuhi standaradisasi KKP HAM harus memenuhi prinsip demokrasi, partisipasi, kepemimpinan yang bertanggung jawab, transparansi, akuntabilitas, non diskriminasi, pemberdayaan, dan supremasi hukum (Antonio, et.al., 2015). Tentunya, implementasi dari pemenuhan KKP HAM ini tetap juga membutuhkan peran penting dari seluruh aktor baik dari lembaga pemerintahan maupun non pemerintahan.

Prinsip-prinsip panduan Gwangju bagi Kota HAM yang disahkan pada tanggal 17 Mei 2014 dalam pertemuan Forum Kota-kota HAM dunia yang Keempat memuat prinsip-prinsip sebuah kota HAM 
sebagai berikut: hak atas kota; non-diskriminasi dan tindakan afirmatif; inklusi sosial dan keragaman budaya; demokrasi partisipatoris dan pemerintahan yang akuntabel; keadilan sosial, solidaritas dan keberlanjutan; kepemimpinan dan pelembagaan politik; pengarusutamaan hak asasi manusia; koordinasi lembaga-lembaga dan kebijakan yang efektif; pendidikan dan pelatihan hak asasi manusia, dan hak atas kompensasi (Antonio, et.al., 2015).

Sedangkan di Negara Indonesia sendiri, pemerintah daerah menjadi salah satu lembaga yang berkontribusi dalam perkembangan di era reformasi dikarenakan adanya pendistribusian kewenangan yang tidak lagi terpusat hanya di pemerintah pusat. Hal tersebut tidak lain adalah sistem desentralisasi yang memungkinkan adanya pembagian beberapa kewenangan dan tanggung jawab pemerintah pusat kepada pemerintahan provinsi maupun pemerintahan kabupaten/kota. Hal ini juga menyangkut tanggung jawab negara terkait perlindungan, pemajuan, penegakan dan pemenuhan HAM. Pemerintahan kabupaten dan kota, oleh karenanya menjelma menjadi representasi negara di tingkat lokal yang bersinggungan langsung dengan warga masyarakat termasuk dalam hal perlindungan, pemajuan, penegakan dan pemenuhan HAM. Semenjak itu, isu HAM selalu berkaitan dengan pemerintahan daerah.

Tentunya, isu untuk segera melibatkan pemerintah daerah agar terlibat dalam penegakan HAM bukanlah hal yang baru. Pada tanggal 23 Juni 2015, Presiden Jokowi telah mengeluarkan Perpres No. 75 Tahun 2015 sebagaimana telah diubah menjadi Perpres No. 33 Tahun 2018 tentang Rencana Aksi Nasional Hak Asasi Manusia (RANHAM) 2015-2019 (Elza Astari Retaduari, 2015). Walaupun peraturan tersebut tidak menjelaskan secara gamblang terkait pembentukan adanya KKP HAM, namun frasa di peraturan tersebut memberikan kesempatan yang besar untuk pemerintah daerah menjalankan agenda-agenda HAM di tingkat daerah. Bahkan terkait KKP HAM, Menteri Hukum dan HAM telah mengeluarkan Peraturan Menteri Hukum dan HAM (Permenkumham) No. 25 tahun 2013 tentang Kriteria Kabupaten/Kota Peduli HAM yang kemudian disempurnakan dengan Permenkumham No. 34 tahun 2016. Permenkumham ini menjadi dasar pemberian predikat daerah peduli HAM kepada beberapa Kabupaten/Kota di Indonesia.

Pemerintah Indonesia juga telah meratifikasi berbagai instrumen HAM internasional yang dapat menjadi landasan untuk mendorong terbentuknya KKP HAM. Instrumen tersebut adalah Kovenan Internasional tentang Hak-Hak Sipil dan Politik, Kovenan Internasional tentang Hak-Hak Ekonomi, Sosial, dan Budaya, Konvensi tentang Penghapusan Segala Bentuk Diskriminasi terhadap Perempuan, Konvensi Hak Anak, Konvensi Internasional tentang Penghapusan Semua Bentuk Diskriminasi Rasial, Konvensi Menentang Penyiksaan dan Perlakuan atau Penghukuman Lain yang Kejam, Tidak Manusiawi, atau Merendahkan Martabat Manusia, Konvensi Perlindungan terhadap Semua Orang dari Penghilangan secara Paksa, Konvensi Perlindungan Hak Semua Buruh Migran dan Anggota Keluarganya, Konvensi Hak Hak Penyandang Disabilitas. Pelaksanaan KKP HAM adalah merupakan bentuk implementasi Konvenan dan Konvensi Internasional tersebut dalam tataran nasional.

Berangkat dari cepatnya respon terhadap penegakan dan perlindungan HAM baik di tingkat global maupun nasional. Komnas HAM menganggap bahwa upaya pembentukan KKP HAM merupakan upaya perlindungan, pemajuan, penegakan dan pemenuhan HAM di Indonesia yang sangat penting dan wajib untuk segera diterapkan di Negara Indonesia. Terlebih lagi, selain dari Gwangju di Korea Selatan, sudah banyak kota di negara lain yang sudah menerapkan seperti Barcelona, Seoul (Korea Selatan), Reykjavik (Islandia) dan masih banyak lagi (Sindi Monica Putri, Weli Febrianto, \& Yosephine Susanto, 2020: 333). Beberapa strategi yang diterapkan setiap kota yang sudah pernah sukses dinobatkan menjadi Kota HAM diantaranya adalah penuangan kebijakan HAM dalam Piagam HAM Gwangju yang diadopsi Kota Gwangju pada tahun 2012 sebagaimana di Kota Gwangju. Sedangkan untuk Barcelona sendiri, pembentukan Kota HAM sebagai langkah responsif dalam menakan tingginya angka diskriminasi di Barcelona. yaitu yang pertama membentuk RDC dan beberapa layanan HAM, yang kedua membentuk kerangka kerja HAM dengan fokus pada keterlibatan Barcelona dalam penyusunan Piagam HAM, mendorong hak perempuan, keempat melaksanakan Piagam ECHR (Sindi Monica Putri, Weli Febrianto, \& Yosephine Susanto, 2020: 333). 
Bagi hukum nasional di Indonesia, sebagai bentuk dari hasil peratifikasian Universal Declaration Of Human Rights yang dideklarasikan oleh PBB. Perlindungan dan pemenuhan terhadap penegakan hak asasi manusia dicantumkan dalam konstitusi bangsa indonesia dalam Pasal 28, 28A-J UUD NRI Tahun 1945, UU HAM dan UU No. 26 Tahun 2000 tentang Pengadilan HAM. Namun tetap, implementasi terhadap nilai-nilai yang tertuang di dalam konstitusi bahkan pancasila, masih dirasa kurang dan belum dirasakan secara langsung dampak baiknya oleh masyarakat. Terlebih, berdasarkan pada data yang dikeluarkan oleh Laporan Tahunan Komnas HAM tahun 2019 bahwa terdapat kasus yang bersifat vertikal, yakni intoleransi yang dilakukan oleh pemerintah, dan kasus yang bersifat horizontal, yakni yang dilakukan oleh kelompok masyarakat/individu (Komnas HAM RI, 2019).

Terdapat 11 kasus intoleransi vertikal yang tersebar di beberapa wilayah, selebihnya merupakan kasus yang besifat horizontal. Pemerintah daerah menjadi pihak teradu tertinggi kasus intoleransi dan ekstrimisme, diikuti oleh lembaga pendidikan dan masyarakat (Komnas HAM RI, 2019). Sehingga, penting untuk meningkatkan optimalisasi penyebaran nilai-nilai pancasila dan konstitusi melalui pelokalan kebijakan HAM di daerah. Tentunya, aktor yang wajib terlibat tidak lain adalah kepala daerah yang memiliki keterlibatan secara langsung untuk mengatur dan mengelola pemerintahan kabupaten/kota sekaligus mengajak warga secara partisipatif menjalankan program pemerintah untuk menegakkan HAM. Dari pemimpin daerah tersebut juga bisa dibuat sebuah produk hukum yang implikatif di daerah sehingga perlindungan HAM di daerah tersebut dapat lebih ditegakkan.

Upaya mewujudkan pelokalan kebijakan HAM di daerah melalui KKP HAM dapat dilakukan dengan beberapa cara, antara lain melalui; perencanaan dan penilaian (assessment), pengembangan kapasitas aparat dan masyarakat sipil yang salah satunya melalui pendidikan dan pelatihan HAM, serta membangun mekanisme HAM lokal dan membangun jejaring nasional (Komnas HAM RI, 2017: 3). Sehubungan dengan ini lembaga HAM Nasional Komnas HAM adalah aktor penting dalam upaya membangun Kota HAM melalui:

a. Pendidikan HAM

Pendidikan HAM adalah semua pembelajaran yang membangun pengetahuan, ketrampilan maupun sikap dan perilaku HAM. Pendidikan HAM membuat orang mampu untuk membuat orang lebih baik dalam mengintergrasikan ke dalam hidup sehari-hari nilai-nilai HAM seperti menghargai, menerima dan memasukkan orang lain. Pendidikan HAM mendorong digunakannya HAM kerangka referensi dalam hubungan kita dengan orang lain. Pendidikan HAM juga mendorong kita untuk secara kritis mengkaji sikap dan perilaku kita sendiri dan, kemudian, mentrasfomasikannya guna meningkatkan perdamaian, harmoni sosial dan penghargaan terhadap hak-hak orang lain. Misalnya dengan mengadakan Seminar dan Focused Group Discussion terkait Internet Sehat dan Pencegahan Ujaran Kebencian. Kegiatan ini mengundang audisi dari kalangan tokoh masyarakat, pemuka agama, mahasiswa, tenaga pendidik, maupun penegak hukum. Tujuan kegiatan ini adalah memberikan pencerahan kepada masyarakat terkait ujaran kebencian sebagai sesuatu yang melanggar HAM yang banyak sekali ditemui akhir-akhir ini terutama bertepatan dengan tahun politik. Lebih khususnya, bertepatan dengan maraknya internet dan media sosial yang menyebarkan informasi ini sangat mudah dan cepat menyebar (Komnas HAM RI, 2017: 4).

b. Kerja sama mewudujkan KKP HAM dengan lembaga non pemerintah dan masyarakat sipil

Pelibatan lembaga non-pemerintah, baik dengan Lembaga Swadaya Masyarakat (LSM), akademisi, dan korporasi, sangat terkait dalam pelaksanaan pembangunan. Keterlibatan berbagai pihak ini memiliki peran penting untuk membantu pemerintah, mengingat tidak semua aktivitas pemenuhan HAM mampu dikerjakan oleh pemerintah sendiri terutama dalam hal ketersediaan skill SDM dan finansial. Bentuk kerja sama yang melibatkan pihak swasta ini dikenal juga dengan istilah public private partnership (PPP) (Ruth Marshinta \& Muh. Khamdan, 2020: 9). Kiprah LSM di Indonesia yang selama ini sering melakukan program-program pendampingan masyarakat merupakan potensi besar bagi berkembangnya sinergi kerja sama HAM tersebut. LSM memiliki bekal kedekatan dengan masyarakat dan diharapkan dapat bergerak bersama 
pemerintah dan swasta untuk memunculkan daya ungkit kesejahteraan warga negara. Pengelolaan dana Corporate Social Responsibility (CSR) menjadi salah satu alternatif kerja sama untuk berbagai program yang sejalan dengan agenda pembangunan nasional, termasuk pemajuan HAM. Peran para profesional yang bekerja di sejumlah LSM, diharapkan pengelolaan dana CSR tersebut dapat dirasakan langsung oleh masyarakat. Sinergi kerja sama multipihak antara pemerintah, swasta, dan masyarakat yang diwakili oleh LSM tentu akan mempercepat implementasi perlindungan, pemajuan, penegakan, dan pemenuhan HAM (Ruth Marshinta \& Muh. Khamdan, 2020: 9).

Kerjasama juga dilakukan dengan masyarakat sipil, antara lain dengan INFID (International NGO for Indonesian Development) dan ELSAM (Lembaga Studi dan Advokasi Masyarakat). Komnas HAM juga bekerja sama dengan Kementerian Hukum dan HAM dan Aparat Pemerintah Daerah di Indonesia. Lebih lanjut, Program Pengarusutamaan Kota HAM menjadi sebuah Program Unggulan (Quick Win) Komnas HAM untuk 2016 - 2017. Komnas HAM menilai pentingnya Implementasi KKP HAM sebagai salah satu cara untuk mengatasi berbagai persoalan dan pelanggaran HAM yang terjadi di Indonesia khususnya di wilayah pemerintah daerah (Komnas HAM RI, 2017: 24). Beberapa hal penting yang dapat dilakukan oleh masyarakat sipil antara lain (Komnas HAM RI, 2017: 24-25):

1) Meninjau mekanisme partisipasi masyarakat dalam perencanaan dan pemantauan kebijakan yang ada, misalnya, meninjau praktik musyawarah perencanaan pembangunan (Musrembang) di daerah setempat.

2) Meninjau mekanisme pelayanan publik.

3) Mengidentifikasi perbaikan yang harus dilakukan untuk optimalisasi partisipasi publik dan pelayanan publik.

4) Mendesain mekanisme partisipasi masyarakat yang menyediakan akses bagi kelompok rentan untuk berpartisipasi secara aktif. Contoh afirmasi adalah Kios Pelayanan Publik Kota Surabaya yang menggunakan 3 bahasa (Indonesia, Jawa dan Madura), atau website yang ramah terhadap penyandang disabilitas netra.

5) Mendesain dan melakukan pelatihan HAM bagi warga.

Peran yang tak kalah penting adalah peran yang dilakukan oleh pers dan media massa.

1) Pers dan media memiliki peran dalam penyebarluasan informasi positif yang mendorong pelaksanaan Kabupaten/Kota HAM oleh pemerintah daerah.

2) Pers dan media juga berperan dalam mengawasi kinerja pemerintah daerah dalam perencanaan dan implementasi kebijakan pembangunan berbasis HAM

c. Kerja sama implementasi RANHAM

Rencana Aksi Nasional HAM (RANHAM) adalah dokumen yang memuat sasaran, strategi dan fokus kegiatan prioritas RANHAM Indonesia dalam pelaksanaan penghormatan, perlindungan, pemenuhan, penegakan dan pemajuan HAM (P-5 HAM) bagi masyarakat Indonesia. Panduan dan rencana umum serta arah bagi penyelenggara negara yang pelaksanaannya bersifat dinamis (living document) serta dapat diselaraskan dengan potensi dan permasalahan di setiap kementerian, lembaga dan pemerintah daerah (Ruth Marshinta \& Muh. Khamdan, 2020: 17). Pelaksanaan RANHAM merupakan amanat dari sejumlah regulasi yang mengatur tentang HAM. Regulasi tersebut meliputi Pasal 28A-J UUD NRI Tahun 1945, Deklarasi Wina 1993, dan UU HAM. Pelaksanaan RANHAM semuanya mempunyai sasaran pada meningkatnya P-5 HAM bagi semua lapisan masyarakat Indonesia baik di pusat maupun daerah (Anton Pradjasto, 2008). 
Terhadap berbagai upaya yang bisa dilakukan dalam mewujudkan pelokalan kebijakan HAM di daerah sebagaimana telah disebutkan di atas, maka terhadap perlindungan, pemajuan, penegakan, dan pemenuhan HAM tersebut harus dilakukan dengan mempertimbangkan nilainilai agama, moral, adat istiadat, budaya, keamanan, ketertiban umum dan kepentingan bangsa Indonesia berdasarkan Pancasila dan UUD NRI Tahun 1945.

\section{KESIMPULAN DAN SARAN}

Salah satu sifat HAM adalah universal. Artinya yaitu, HAM berlaku bagi setiap orang tanpa memandang latar belakang suku, agama, ras, dan kelompok apapun. Oleh sebab bersifat universal, maka negara wajib menegakkan hak asasi setiap warga negaranya tanpa terkecuali. Di Indonesia, penegakkan HAM harus didasarkan pada pancasila sebagai ideologi bangsa dan konstitusi sebagai dasar negara. Kewajiban negara dalam menegakkan HAM tersebut tidak hanya mengikat pemerintah pusat, namun juga cabang kekuasaan di bawahnya, seperti pemerintah daerah. Kondisi ini yang kemudian melahirkan adanya suatu gagasan untuk melakukan pelokalan terhadap kebijakan HAM di daerah. Dalam rangka pelokalan kebijakan HAM di daerah, aktualisasi nilai-nilai pancasila dan konstitusi tidak bisa terpisahkan. Hal ini mengingat bahwa pancasila dan konstitusi merupakan ide dasar atau bangunan yang diidealkan dalam konteks kehidupan berbangsa dan bernegara, terlebih dalam penegakan HAM. Adapun bentuk upaya dalam merealisasikan pelokalan kebijakan HAM di daerah ini dilakukan melalui KKP HAM yang mencakup: perencanaan dan penilaian (assessment); pengembangan kapasitas aparat dan masyarakat sipil yang salah satunya melalui pendidikan dan pelatihan HAM; serta membangun mekanisme HAM lokal dan membangun jejaring nasional.

\section{UCAPAN TERIMAKASIH}

Kami ingin mengucapkan rasa syukur kepada Allah Swt. atas limpahan rahmat dan nikmatnya, terutama nikamat sehat dan sempat sehingga Penulis bisa menyelesaikan artikel ini. Kami juga tidak lupa menyampaikan terimakasih kepada keluarga atas dukungan dan doanya, serta para pembimbing kami yang telah memberikan banyak masukan terkait artikel ini.

\section{Conflict of Interests}

The authors declared that no potential conflicts of interests with respect to the authorship and publication of this article.

\section{DAFTAR PUSTAKA}

Aminanto, K. 2018. Bunga Rampai Hukum: Supremasi Hukum, Hak Cipta, Human Right, Integritas. Katamedia. Jember.

Antonio, et.al. (2015. Panduan Kabupaten dan Kota Ramah Hak Asasi Manusia. International NGO Forum on Indonesian Development. Infid.

Asshiddiqie, J. (2009). Ideologi, Pancasila, dan Konstitusi. Diakses dari https://jakarta45.wordpress.com/2009/08/08/konstitusi-ideologi-pancasila-dan-konstitusi/amp/.

Asshiddiqie, J. (Maret 2008). Konstitusi dan Hak Asasi Manusia. Makalah disampaikan pada Lecture Peringatan 10 Tahun KontraS. Jakarta. 
Coming, S., \& Robert N. L. (eds). 1953. Man and the state: The Political Philosophers. Modem Library. Random House.

Ford, L. (2015). Sustainable Development Goals: All You Need to Know. Diakses dari https://www.theguardian.com/global-development/2015/jan/19/sustainable-development-goalsunited-nations.

Irmansyah, R. 2013. Hukum, Hak Asasi Manusia, dan Demokrasi. Graha Ilmu. Yogyakarta.

Iswardhana, M. R. 2020. Pendidikan Pancasila dan Kewarganegaraan: Merajut Kebinekaan dalam Menghadapi Tantangan Revolusi Industri. PT Kanisius. Yogyakarta.

Junaenah, I., \& Sungkar, L. (2017). Model Panduan Kriteria Desa Peduli Hak Asasi Manusia dalam Konteks Jawa Barat. Jurnal Ilmu Hukum, 4(3).

Kementerian Hukum dan HAM. (2020). 59\% Kabupaten/Kota di Indonesia Peduli HAM. Diakses dari https://www.kemenkumham.go.id/berita/59-kabupaten-kota-di-indonesia-peduli-ham.

Komnas HAM RI. 2017. Kertas Posisi Kabupaten/Kota HAM (Human Rights Cities). Komisi Nasional Hak Asasi Manusia. Jakarta.

Komnas HAM RI. 2019. Laporan Tahunan Komnas HAM 2019. Komisi Nasional Hak Asasi Manusia. Jakarta.

Marshinta, R., \& Khamdan, M. 2020. Membangun Kerja Sama HAM: Kewajiban Negara dalam Implementasi Pemenuhan dan Perlindungan HAM di Indonesia. Pohon Cahaya \& BPSDM KUMHAM Press. Depok.

Martosoewignjo, S. S. 1992. Bunga Rampai Hukum Tata Negara Indonesia. Alumni. Bandung.

Nurkhoirun, M. 2017. Mengembangkan Kota Ham di Indonesia: Peluang dan Tantangannya. Jurnal Pemikiran Sosiologi, 4, 120-121.

Peraturan Menteri Hukum dan HAM Nomor 25 Tahun 2013 tentang Kriteria Kabupaten/Kota Peduli HAM

Peraturan Menteri Hukum dan HAM Nomor 34 Tahun 2016 tentang Kriteria Kabupaten/Kota Peduli HAM

Peraturan Presiden Nomor 33 Tahun 2018 tentang Perubahan atas Peraturan Presiden Nomor 75 Tahun 2015 tentang Rencana Aksi Nasional Hak Asasi Manusia (Lembaran Negara Republik Indonesia Tahun 2018 Nomor 57; LL SETKAB)

Pradjasto, A. (November 2008). Instrumen Hak Asasi Manusia dan Konsep Tanggung Jawab Negara". Makalah disampaikan pada Pelatihan Dasar HAM Kerjasama Direktorat Jendral HAM dan Raoul Wallenberg Institute (RWI), Pengembangan Kapasitas Panitia RAN-HAM 20042009. Jakarta.

Putri, S. M., Febrianto, W., \& Susanto, Y. (2020). Urgensi Yogyakarta Menjadi Kota Ramah HAM sebagai Upaya Perlindungan bagi Mahasiswa Papua di Yogyakarta. Jurist-Diction, 3(1).

Retaduari, E. A. (2015). Pemerintah Luncurkan Kebijakan Kota Ramah HAM Awal Desember. Diakses dari https://news.detik.com/berita/d-3080305/pemerintah-luncurkan-kebijakan-kotaramah-ham-awal-desember/komentar.

Supriyanto, B. H. (2014). Penegakan Hukum mengenai Hak Asasi Manusia (HAM) menurut Hukum Positif di Indonesia. Jurnal Al-Azhar Indonesia Seri Pranata Sosial, 2(3).

Undang-Undang Dasar Negara Republik Indonesia Tahun 1945

Undang-Undang Republik Indonesia Nomor 26 Tahun 2000 tentang Pengadilan Hak Asasi Manusia (Lembaran Negara Republik Indonesia Tahun 2000 Nomor 208; Tambahan Lembaran Negara Republik Indonesia Nomor 4026)

Undang-Undang Republik Indonesia Nomor 39 Tahun 1999 tentang Hak Asasi Manusia (Lembaran Negara Republik Indonesia Tahun 1999 Nomor 165; Tambahan Lembaran Negara Republik Indonesia Nomor 3886) 